\title{
REVIEW OF THE COLLECTED STORIES OF MACHADO DE ASSIS, TRANSLATED BY MARGARET JULL COSTA AND ROBIN PATTERSON
}

\section{RESENHA DE THE COLLECTED STORIES OF MACHADO DE ASSIS, TRANSLATED BY MARGARET JULL COSTA AND ROBIN PATTERSON}

ASSIS, Machado de. The Collected Stories of Machado de Assis. Trans. Margaret Jull Costa and Robin Patterson. New York: Liveright, 2018. 934 p.

\section{FLORA THOMSON-DEVEAUX}

Independent researcher

Rio de Janeiro, Rio de Janeiro, Brasil

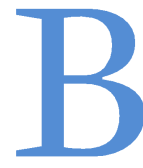

$\mathrm{y}$ any measure, the Collected Stories of Machado de Assis (ASSIS, 2018) is a welcome addition to the family of Machadian translations. Margaret Jull Costa and Robin Patterson's anthology-by far the largest Englishlanguage volume of Machado stories to date, and from a high-profile publishing house-includes all of the stories published in book form during the author's lifetime. Of the more than 200 stories that Machado published over the course of his life, in periodicals as well as anthologies, this collection includes 76, ten of which appear in English for the first time: "Luís Soares," "Linha reta e linha curva" (Straight Line, Curved Line), "Luís Duarte" (Luís Duarte's Wedding), "Ernesto de Tal" (Ernesto What's-His-Name), "Aurora sem dia" (Much Heat, Little Light), "Dona Benedita," "O segredo do bonzo" (The Bonze's Secret), "O 
anel de Polícrates" (Polycrates's Ring), "Último capítulo" (Final Chapter) and "O lapso" (The Lapse). ${ }^{1}$

This alone represents a significant gain. Although the first English-language translation of one of Machado's short stories had come a full century earlier, subsequent editorial efforts tended to favor a fairly limited range of narratives, only branching out in a flurry of anthologies over the last half decade. In a 2015 article, Luana Ferreira de Freitas and Cynthia Beatrice Costa surveyed Englishlanguage translations of Machado's stories and observed that these publications tended to privilege the author's later work (as with the novels, the first of which to enter English was Memórias póstumas de Brás Cubas, in 1952, and the last of which was Ressurreição, in 2013). "O Enfermeiro," "O Alienista," and "A Cartomante" were the most relentlessly translated pieces, to the point that the authors of the study jokingly refer to them as "mandatory" inclusions in any English-language collection of Machado stories. Freitas and Costa (2015) counted a total of 82 translated stories as of early 2015; when we add the seven new translations from Miss Dollar: Stories by Machado de Assis (ASSIS, 2016) and the ten from the Collected Stories, that brings us up to 99. That total, suffice to say, accounts for nearly all of the stories that most casual or less-than-casual Machado readers would be familiar with; among the hundred-odd narratives awaiting translation are "Nem uma nem outra," "O óculos de Pedro Antão," and "Pobre cardeal!"

Whereas many previous publications of Machado's short stories chose to highlight one of the better-known works in their titles ("A missa do galo," "O alienista," and "A igreja do diabo" have lent their names to a few), the chronological structure of the Collected Stories means that English speakers looking for an introduction to Machado de Assis will begin not with the "greatest hits" but with the only belatedly translated 1870 Contos Fluminenses and gradually work their way through to better-known narratives. While logical, this represents a novelty for Anglophones, allowing readers to follow Machado's development as a short story writer over the course of two decades. In line with this decision to preserve the structure of each story collection, Jull Costa and Patterson's presence is generally discreet. They have provided no preface of their

\footnotetext{
${ }^{1}$ Jull Costa and Patterson's collection is said to include 12 pioneering translations; I believe that this fails to account for "O relógio de ouro" and "Ponto de vista," which were translated by Juan LePuen in the 2014 ebook Midnight Mass and Other Stories (ASSIS, 2014).
} 
own and eschew notes-not an obvious decision, since the stories make reference to incidents and concepts that may be remote even for many Brazilian readers.

While, as noted, the vast majority of the stories in this anthology had been previously translated (some debuting in English only a few years ago), repetition is not redundancy; each fresh translation of these remarkable narratives enriches our readings of them. The comparative analysis of translations can shed light on the experience of the reader-the translations' divergences revealing the points at which the text forces the reader/translator to shoulder the greatest interpretive burden-and let us see the original anew. In this spirit, I would like to appraise the Collected Stories by taking a look at how the anthology tackles one of Machado's most-translated short stories ("O alienista") and one of his leasttranslated short stories ("O relógio de ouro," which had only been published once before, in an e-book in 2014 [ASSIS, 2014]). In the latter case, a seemingly naïve tale reveals unsuspected complexity as it branches outward in translation. In the case of "O alienista," a comparative reading of existing translations can help us glimpse patterns of decision-making by Jull Costa and Patterson, as well as shed light on instances in which Machado ingeniously weaves together references in ways that have thus far stymied all comers.

"O alienista," the saga of the ambitious and fatally rational mental health practitioner Simão Bacamarte, was first published in English in 1963, translated by William Grossman as "The Psychiatrist" (ASSIS, 1963) It was followed by Rhett McNeil's 2014 translation of the same title, as well as versions by John Chasteen in 2013 and Jull Costa and Patterson in 2018, both titled "The Alienist." (The former title has been criticized as anachronistic; Grossman's translation was later lightly edited and rereleased as "The Alienist.")

This range of versions of the same text provides a rich basis for comparison. To judge the nature of a translation and arrive at a more specific sense of the patterns that it displays, it is often more productive to read it against existing interpretations in the same language than to hold it to the virtually impossible standard of the origin language. In setting the four translators side by side, we can examine manifestations of the style and philosophy behind each of their translations as well as the ways in which they illuminate the possibilities inherent in the source text-or, as the case may be, visibly run up against its difficulties. Here, for brevity's sake, we will only examine the first chapter of the story. 
Since Jull Costa and Patterson's translation is the object of interest here, I have privileged observations about their style. The diction of their translation bobs and weaves to fit Machado's fluctuating tone, going from the informality of "meteu-se em Itaguaí" (ASSIS, 1979, p. 253), or "took himself off to Itaguai" (ASSIS, 2018, p. 315), to Bacamarte's reference to "louros imarcescíveis" (ASSIS, 1979, p. 254), or "ever-lasting laurels" (ASSIS, 2018, p. 316). This is made clearer by contrast, as Grossman, Chasteen, and McNeil adopt more formal solutions for the first example ("took up residence" [ASSIS, 1963, p. 1] for the former and "returned to" [ASSIS, 2013b, np; ASSIS, 2013a, p. 1] for the latter two), making it more difficult to detect a difference in tone in relation to the second. The duo seem to take particular care not to seek out easy equivalents, preferring "nooks and crannies" (ASSIS, 2018, p. 316) to "corner" when translating the phrase "recanto psíquico" (ASSIS, 1979, p. 254). When faced with "O escrivão perdeu-se nos cálculos aritméticos" (ASSIS, 1979, p. 255), Grossman and Chasteen report that the civil servant got "lost" in his calculations (ASSIS, 1963, p. 3; ASSIS, 2013b, $\mathrm{np}$ ), whereas in the Collected Stories and in McNeil's translation he is said to have gotten into "a terrible muddle" (ASSIS, 2018, p. 317) and "mixed up" (ASSIS, 2013a, p. 4), respectively. The pair also find an elegant solution for the parallelism of Machado's description of the local lunatics as "não curado[s], mas descurado[s]" (ASSIS, 1979, 254), in "uncured and uncared-for" (ASSIS, 2018, p. 316).

These comparisons verge on impressionistic; but one element that bucks subjectivity is the treatment of culturally and historically specific terms. In this excerpt, the team of translators generally preserves them; whereas in 1963 Grossman translated "Rua Nova" as "New Street" and glossed two "tostões" as "a tax of a stated amount," (ASSIS, 1963, p. 3) Jull Costa and Patterson preserve the Portuguese-language terms (ASSIS, 2018, p. 317). On the unforgiving binary between domestication and foreignization, this would place them closer to the second extreme, expecting readers to be able to navigate these presumably unfamiliar systems of street nomenclature and currency. Chasteen and McNeil split the difference, keeping "Rua Nova" but glossing "tostões" as "an hourly rate" (ASSIS, 2013b, np) and "two nickels" (ASSIS, 2013a, p. 4), respectively.

On the whole, one senses a paradigm shift between the first translation and the rest, unsurprising in light of the half-century that separates them. Grossman, as with his translation of Memórias póstumas de Brás Cubas, intervenes much 
more actively than his twenty-first-century colleagues in terms of altering sentence structure and emphasis. For example, his description of Dona Evarista, who "possessed a face composed of features neither individually pretty nor mutually compatible" (ASSIS, 1963, p. 1) is, while certainly entertaining, much less understated than "D. Evarista era mal composta de feições" (ASSIS, 1979, p. 253). All of the subsequent translators are more inclined to follow the structure of Machado's sentences, although Jull Costa and Patterson's version, perhaps unintentionally, omits the sentence beginning "A ideia de meter os loucos na mesma casa, vivendo em comum [...]" (ASSIS, 1979, p. 254).

In addition to helping systematize observations about the translators' styles, these comparisons often reveal unyielding points of difficulty posed by the original. Indeed, the first chapter of "O Alienista" also includes a phrase whose sheer peculiarity is systematically diluted in translation. Upon Simão Bacamarte's marriage to the unprepossessing Dona Evarista, his uncle feels obliged to comment on the improbable match. In this context, Machado describes the uncle as follows: "caçador de pacas perante o Eterno, e não menos franco" (ASSIS, 1979, p. 254). Grossman and Chasteen describe the uncle as "outspoken" (ASSIS, 1963, p. 1) and "blunt" (ASSIS, 2013b, np), respectively, simply translating "franco" and leaving out the rest; while Jull Costa and Patterson characterize him as "an inveterate meddler in the affairs of others" (ASSIS, 2018, p. 315). McNeil, meanwhile, sees him as "an incorrigible ladies' man known for his frankness" (ASSIS, 2013a, p. 1), interpreting the "pacas" as women, presumably ones more conventionally attractive than Dona Evarista.

The construction "caçador perante o Eterno" is a Biblical reference to King Nimrod, traditionally reproduced in English as "a mighty hunter before the Lord," with a paca-a largeish, spotted South and Central American rodentsandwiched into it. In my interpretation, which seems to be shared by Jull Costa and Patterson, this combination conveys both the uncle's sense of selfimportance (mighty hunter) and the true scale of his activities (in the form of the humble paca). One might consider substituting the animal with another rodent that would give English-language readers a sense of the inglorious task of hunting it-perhaps "mighty squirrel-hunter before the Lord." Regardless of the solution,

${ }^{2}$ Among the challenges that laypeople may not imagine lie in wait for the translators of Machado de Assis is deciding which rodent is funniest: squirrels, gophers, mice, or chipmunks? Moreover, would it be 
this ripple, often smoothed out in translation, may point us to the often overlooked strangeness of Machado's turns of phrase. I believe this one is particularly emblematic in its nonchalant combination of local color and canonical references, producing a synthesis that has thus far been lost in paraphrase.

From "O Alienista," we can turn to a much less read-and thus much less translated-narrative. I perused Jull Costa and Patterson's translation of "O relógio de ouro" with some curiosity, as I had previously translated an excerpt from it for João Cezar de Castro Rocha's book Machado de Assis: Toward a Poetics of Emulation. This is, in my translation, how he presents the excerpt from the story:

"O relógio de ouro" [The Gold Watch], published in the Jornal das Famílias in April and May of 1873 and reproduced later the same year in Midnight Stories, presents a simple anecdote that serves to herald the complexity of future approaches to the subject. All revolves around an innocent suspicion, which is resolved easily: the man's watch found by zealous Luís Negreiros was no proof of infidelity, but a birthday present from his wife herself. (ROCHA, 2015, p. 32)

Guided by this interpretation, I had translated the end of the story, in which Luís Negreiros' wife Clarinha presents him with the card accompanying the watch, as follows:

Luís Negreiros recebeu a carta, chegou-se à lamparina e leu estupefato estas linhas:

"Meu nhonhô. Sei que amanhã fazes anos; mando-te esta lembrança.

Tua Iaiá" (ASSIS, 1979, p. 240)

Luís Negreiros took the letter, brought it to the lamp, and read these lines with utter stupefaction:

My darling husband. I know that your birthday is tomorrow; I have sent you this gift.

Your wife. (ROCHA, 2015, p. 33)

biologically permissible to swap out a rodent for a marsupial in the name of bringing the phrase "mighty possum-hunter before the Lord" into English? 
I'd thought that the trickiest part of this passage was dealing with nhonho and iaiá-a linguistic challenge that I ultimately sidestepped, using Castro Rocha's reading to decode these historically freighted pet names into "husband" and "wife." When I read Jull Costa and Patterson's translation, however, I was surprised. Theirs went as follows:

Luís Negreiros took the letter, went over to the lamp, and was astonished to read these words:

My dear young master. I know that tomorrow is your birthday, and so I'm sending you this small gift.

Nanny. (ASSIS, 2018, p. 290)

Where I had read husband and wife, my colleagues decoded nhonhô and iaiá as another relationship entirely. In an e-published version of the story translated by Juan LePuen in 2014, meanwhile, the note appears as follows:

Luís Negreiros took the letter, went over to the lamp, and, thunderstruck, read these lines:

My nhonhô. I know it's your birthday tomorrow; I'm sending you this gift.

- Aunt Iaiá. (ASSIS, 2014, np) ${ }^{3}$

This fresh divergence prompted me to consult the ending of the story as it was published in the Jornal das Famílias in 1873. In this earlier version, the note was signed by one Zepherina, and the narrative concluded as follows:

"Meu bebê. Sei que amanhã fazes annos; mando-te esta lembrança.

- Tua Zepherina."

Imagine o leitor o pasmo, a vergonha, o remorso de Luiz Negreiros, admire a constancia de Clarinha e a vingança que tomára, e de nenhum modo lastime a boa Zepherina, que foi totalmente esquecida, sendo perdoado Luiz Negreiros, e tendo Meirelles o gosto de jantar com a filha e o genro no dia seguinte. (ASSIS, 1873, p. 132)

${ }^{3}$ LePuen's translation does not indicate which source text he used for his translations; this interpretive decision may have been informed by the version of the story provided at dominiopublico.gov.br, in which the signature on the note is mis-transcribed as "Tia Iaiá." 
Suddenly the story made more sense: Clarinha's silent indignation when her husband believed the watch to have been a present from her, when she knew it was from his mistress. When tasked with interviewing Jull Costa and Patterson about their translation for Suplemento Pernambuco in 2018, I wrote to say that I thought we'd all got it wrong: not the wife herself, not the nanny, not an aunt, Iaiá might well have been the Other Woman. "Machado seems to have made the switch to nhonhô/iaiá to keep the ending deliberately indeterminate," I commented, "which none of us did!" In her response, Jull Costa (2018) argued: "I read the current ending as Luís having destroyed a previously happy marriage by his senseless jealousy."

While we can debate the relative likelihood of an upper-class mistress versus a onetime nanny being able to afford a gold watch as a gift, one may say of Luís Negreiros what Antonio Candido wrote about Dom Casmurro: "não importa muito que a convicção de Bento seja falsa ou verdadeira, porque a consequência é exatamente a mesma nos dois casos: imaginária ou real, ela destrói a sua casa e a sua vida" (CANDIDO, 1970, p. 25). Machado's revision of the story not only removes the unambiguous author of the letter, it also removes the happy ending. Whoever the female giver of the watch, we may be certain of the husband's fury and the wife's icy silence, neither wiped away so easily. Moreover, and perhaps more importantly, this persistent divergence among translators and readers regarding such a seemingly "simple" narrative is a striking demonstration of how Machado's ambiguous language dovetails with the cultural complexities of Brazilian Portuguese to create interpretive "knots."

These are a few examples plucked from the nearly thousand pages of the Collected Stories. For scholars, the anthology may give rise to many more fresh appreciations of Machado through the lens of English, given the new translations and reinterpretations it presents. For English-language friends of Machado, the breadth and prominence of the collection alone would make it a valuable contribution in and of itself, but Jull Costa and Patterson's careful readings cement that effort. 


\section{References}

ASSIS, J. M. Machado de. O relógio de ouro. Jornal das Famílias, Rio de Janeiro, n. 4-5, 1873, p. 117-120; p. 129-132.

The Psychiatrist and Other Stories. Trans. William L. Grossman and Helen Caldwell. Berkeley: University of California Press, 1963. . Obra completa. Rio de Janeiro: Nova Aguilar, 1979. v. II. Stories. Ed. and trans. Rhett McNeil. Champaign: Dalkey, 2013a. . The Alienist and Other Stories of Nineteenth-Century Brazil. Ed. and trans. John Charles Chasteen. Indianapolis: Hackett, 2013b. Midnight Mass and Other Stories. Trans. Juan LePuen. Fario, 2014. Miss Dollar: Stories by Machado de Assis. Ed. Glenn Alan Cheney. Trans. Greicy P. Bellin and Ana Lessa-Schmidt. Hanover: New London Librarium, 2016. . The Collected Stories of Machado de Assis. Trans. Margaret Jull Costa and Robin Patterson. New York: Liveright, 2018.

CANDIDO, Antonio. Esquema de Machado de Assis. In: —_. Vários escritos. São Paulo: Livraria Duas Cidades, 1970.

FREITAS, Luana Ferreira de; COSTA, Cynthia Beatrice. Machado contista em antologias de língua inglesa. Cadernos de Tradução, Florianópolis, v. 35, n. 1, p. 69-85, jan-jun 2015.

JULL COSTA, Margaret. [Correspondência]. Destinatário: Flora Thomson-DeVeaux. 5 set 2018. E-mail pessoal.

ROCHA, João Cezar de Castro. Machado de Assis: Toward a Poetics of Emulation. Trans. Flora Thomson-DeVeaux. East Lansing, MI: Michigan State University Press, 2015.

FLORA THOMSON-DEVEAUX is a writer and translator with a $\mathrm{PhD}$ in Portuguese and Brazilian Studies from Brown University. She has published essays such as "Nota sobre 0 calabouço" (piaui_140) and "\#charlottesville" (piaui_132), and translations, most recently Pedro Meira Monteiro's The Other Roots: Wandering Origins in Sérgio Buarque de Holanda's Roots of Brazil and the Impasses of Modernity in Ibero-America (Notre Dame, 2017); Lena Lavinas' The Takeover of Social Policy by Financialization: The Brazilian Paradox (Palgrave, 2017); and João Cezar de Castro Rocha's Machado de Assis: Toward a Poetics of Emulation (Michigan, 2015). (D) https://orcid.org/0000-0003-2634-7945. E-mail: flora.td@gmail.com

Recebido: 17.10 .2019

Aprovado: 18.10 .2019 